\title{
Susceptibility to Rust (Puccinia Sp.) in Cultivars of Italian and Perennial Ryegrass Grown in Two Locations of Italy
}

\author{
Luigi Russi ${ }^{1^{*}}$, Massimo Romani², Luciano Pecetti ${ }^{2}$ \\ ${ }^{1}$ Dipartimento di Biologia Applicata, Università degli Studi di Perugia \\ Borgo XX Giugno 74, 06121 Perugia, Italy \\ ${ }^{2}$ CRA, Centro di Ricerca per le Produzioni Foraggere e Lattiero-casearie \\ Viale Piacenza 29, 26900 Lodi, Italy
}

Received: 1 December 2008. Accepted: 30 March 2009.

\begin{abstract}
A large set of foreign varieties of Italian ryegrass (Lolium multiflorum) and perennial ryegrass (L. perenne) were evaluated for their response to natural rust infection in two Italian locations (Lodi in the north; Perugia in the centre of the country) at three-year intervals in 2001, 2004 and 2007, to acquire information on novel germplasm for Italy and verify any spatial and temporal variation in the varietal response to the disease. Crown rust (caused by Puccinia coronata) on Italian ryegrass and stem rust (caused by $P$. graminis) on perennial rygrass were consistently recorded in appreciable amount (average susceptibility score $>2.0$ on a 1-9 scale). Vice-versa, crown rust on perennial and stem rust on Italian ryegrass seldom affected appreciably the crop. Strong interactions of variety response (to the prevailing pathogen) with locations and years of evaluation were observed in both ryegrasses. Subsequently, the repeatability of results between locations, or between years within locations, as measured by rank correlations of variety scores, was sometimes only moderate or low. However, despite such interactions, a few promising varieties were identified in each species with consistently low susceptibility across evaluation environments, which deserve further investigation for a possible direct utilisation, or as donors of useful genes for breeding purposes.
\end{abstract}

Key-words: Lolium multiflorum, Lolium perenne, Puccinia coronata, Puccinia graminis, rust, ryegrass.

\section{Introduction}

Italian ryegrass (Lolium multiflorum Lam.) and perennial ryegrass (L. perenne L.) are two of the most important pasture and forage grass species throughout the temperate zones of the world (Jung et al., 1996). In Italy, Italian ryegrass was extensively used in the past as a component of sown mixed grasslands, while nowadays it is a basic element of the very intensive forage-livestock system widespread in the northern plain of the country (Tomasoni et al., 2003). Perennial ryegrass, which shows a marked preference for cool and moist environments, is also largely sown in mixed swards, where its rapid germination and early seedling establishment provide early herbage production. In addition to its interesting features as a forage crop, perennial ryegrass is a very important cool-season turfgrass species worldwide (Beard, 1973).
Rust (caused by Puccinia sp.) is the most threatening foliar disease in ryegrasses (Jung et al., 1996), widespread throughout Europe (Potter et al., 1990) and elsewhere (Aldaoud et al., 2004). When infection is advanced, the plant surface becomes reddish/brown because of the powdery urediniospore masses. Plants may even die for the lesions and the excessive water loss. Negative economic effects of rust infections include: (i) severe losses in dry-matter yield; (ii) a reduction of water-soluble carbohydrates and, hence, of forage digestibility; and (iii) a diminished competitive ability of the plant (Potter, 1987), causing, in turn, a depletion of the stand density.

Although the chemical control of pathogens is effective, fungicide treatments may be expensive and ever less accepted by the public opinion. The availability of resistant/tolerant culti-

* Corresponding Author: Tel.: +39 075 5856286; Fax +39 075 5856224. E-mail address: lrussi@unipg.it 
vars represents, therefore, the best option to control the disease. Rust resistance has generally been treated as a polygenic system, and phenotypic recurrent selection is the most adopted selection method (Kimbeng, 1999). Breeding programmes implemented in ryegrasses make use of the existing genetic variation in the response to rust in order to select the healthiest germplasm in naturally-infected field nurseries or in controlled environments under a composite inoculum (Hayward, 1977; Hides and Wilkins, 1978; Rose-Fricker et al., 1986; Clarke et al., 1997; Kimbeng, 1999). Either approach has the disadvantage, however, that physiological races of the pathogen not included in the breeding process may overcome later on the resistance of selected germplasm. Different races with variable virulence on Italian or perennial ryegrass genotypes have been reported within Europe (Potter et al., 1990; Schubiger et al., 2007a) and Australia (Aldaoud et al., 2004).

This study aimed at assessing in two different environments of Italy the response to natural rust infection in a wide range of European varieties of the two Lolium species. The research was carried out in the framework of a European network to monitor the susceptibility to rust of ryegrass varieties, which is promoted by the Fodder Crops and Amenity Grasses Section of Eucarpia (European Association for Plant Breeding Research) and includes over 30 sites in more than ten countries (Boller et al., 2003a; Schubiger et al., 2007b). The Italian locations of Lodi and Perugia were comprised in the network, being its two southernmost sites. The geographic distance between the two locations might imply the presence of local races of the pathogens and, hence, different levels of susceptibility in the tested varieties. The assessment was carried out thrice, at three-year intervals, to verify any temporal and/or spatial variation in the variety responses to the disease. The duration of any resistance to pathogens, which may be limited by the appearance of new virulent races, and the stability of response are indeed overriding criteria in breeding programmes.

\section{Materials and methods}

In 2001, 2004 and 2007 the evaluation was carried out at the same time in $\operatorname{Lodi}\left(45^{\circ} 19^{\prime} \mathrm{N}\right.$, $\left.9^{\circ} 30^{\prime} \mathrm{E}\right)$ and Perugia $\left(43^{\circ} 03^{\prime} \mathrm{N}, 12^{\circ} 23^{\prime} \mathrm{E}\right)$. The former is a typical site of the northern Italian plain, characterised by sub-continental climate, with a mean annual rainfall of $802 \mathrm{~mm}$ and a mean temperature of $12.2{ }^{\circ} \mathrm{C}$. The latter location, in inner central Italy, features a transition climate between the Mediterranean and the sub-continental climate, with a mean annual rainfall of $794 \mathrm{~mm}$ and a mean temperature of $13.5^{\circ} \mathrm{C}$.

The experimental layout was the same in the two locations and in the three years of evaluation, with the establishment of two contiguous trials, each one according to a randomised complete block design with four replications. In each block, each variety was sown in spring at a rate of $1 \mathrm{~g} \mathrm{seed} / \mathrm{m}$ in a row-plot, $3 \mathrm{~m}$ long and 0.5 $\mathrm{m}$ apart from contiguous rows. One trial included 15 varieties of Italian ryegrass and three of hybrid ryegrass (Lolium $x$ boucheanum Kunth). These latter were described as more similar to Italian ryegrass than perennial ryegrass and were, therefore, included in this trial, comprising eight diploid and ten tetraploid varieties. The other trial encompassed 33 varieties of perennial ryegrass, of which 19 were diploid and 14 tetraploid. The majority of perennial ryegrass varieties (20 out of 33), and nearly the half of Italian and hybrid ryegrass varieties (eight out of 18) were released less than ten years before the first run of the evaluation (the complete list of varieties in each trial is reported in the following Tabb. 3 and 4). As each participant in the European network was allowed to nominate two cultivars for each trial planted, and even though not all participants used their allowance completely (none of the varieties were released in Italy), the geographic origin of the tested varieties was very diversified.

The trials in Lodi received a total of $90 \mathrm{~mm}$ (three applications), $60 \mathrm{~mm}$ (two applications) and $70 \mathrm{~mm}$ (two applications) of irrigation in 2001, 2004 and 2007, respectively. In Perugia the trials received a total of $60 \mathrm{~mm}$ per year, given in two applications, viz half at sowing to enhance germination and plant establishment, and the rest after the first cut of the season. Total rainfall in the March-October evaluation period of each year was $485 \mathrm{~mm}, 517 \mathrm{~mm}$ and 402 $\mathrm{mm}$ in Lodi, and $387 \mathrm{~mm}, 536 \mathrm{~mm}$ and $309 \mathrm{~mm}$ in Perugia; respectively. In the same period of each year, the mean daily temperature was 17.6 
Table 1. Dates of disease scoring in the two Italian locations and three years of evaluation. In parentheses, scored pathogen: $\mathrm{cr}=$ crown rust $($ Puccinia coronata $) ; \mathrm{sr}=$ stem rust (Puccinia graminis); underlined are the records meeting the minimum requirement of an average score value $>$ 2.0 and thus used in the data analysis.

\begin{tabular}{|c|c|c|}
\hline \multirow[t]{2}{*}{ Species/year } & \multicolumn{2}{|l|}{ Location } \\
\hline & Lodi & Perugia \\
\hline \multicolumn{3}{|c|}{ Italian ryegrass $^{1}$} \\
\hline \multirow[t]{3}{*}{2001} & 22 Jun ( $\underline{\mathrm{cr}}$ ) & $30 \mathrm{Jul}$ (드) \\
\hline & $20 \mathrm{Jul}(\underline{\mathrm{cr}})$ & $20 \mathrm{Aug}(\underline{\mathrm{cr}}, \mathrm{sr})$ \\
\hline & 15 Oct $(\underline{\mathrm{cr}})$ & 27 Sep (ㄷ, sr) \\
\hline \multirow[t]{3}{*}{2004} & $16 \mathrm{Jul}(\underline{\mathrm{cr}})$ & 26 Aug ( $\underline{\mathrm{cr}})$ \\
\hline & $17 \mathrm{Aug}(\underline{\mathrm{cr}})$ & 7 Oct ( $\underline{\mathrm{cr}}, \mathrm{sr})$ \\
\hline & $3 \operatorname{Sep}(\underline{\mathrm{cr}})$ & \\
\hline \multirow[t]{3}{*}{2007} & 15 Jun ( (cr, sr) & $20 \mathrm{Jul}$ (모, sr) \\
\hline & $16 \mathrm{Jul}(\underline{\mathrm{cr}}, \mathrm{sr})$ & \\
\hline & 27 Jul (모) & \\
\hline \multicolumn{3}{|c|}{ Perennial ryegrass } \\
\hline \multirow[t]{3}{*}{2001} & 22 Jun ( $\underline{\text { sr}})$ & $30 \mathrm{Jul}(\mathrm{cr}, \underline{\mathrm{sr}})$ \\
\hline & $20 \mathrm{Jul}(\underline{\mathrm{sr}})$ & $20 \mathrm{Aug}(\mathrm{cr}, \underline{\mathrm{sr}})$ \\
\hline & & $27 \operatorname{Sep}(\mathrm{cr}, \underline{\mathrm{sr}})$ \\
\hline \multirow[t]{3}{*}{2004} & $20 \mathrm{Jul}(\underline{\mathrm{sr}})$ & $26 \mathrm{Aug}(\mathrm{cr}, \underline{\mathrm{sr}})$ \\
\hline & $17 \mathrm{Aug}(\underline{\mathrm{sr}})$ & 7 Oct $(\mathrm{cr}, \underline{\mathrm{sr}})$ \\
\hline & $3 \operatorname{Sep}(\underline{\mathrm{cr}})$ & \\
\hline \multirow[t]{3}{*}{2007} & 15 Jun ( $\underline{\mathrm{sr}})$ & \\
\hline & $16 \mathrm{Jul}(\underline{\mathrm{sr}})$ & \\
\hline & $27 \mathrm{Jul}(\underline{\mathrm{cr}})$ & $20 \mathrm{Jul}(\mathrm{cr}, \underline{\mathrm{sr}})$ \\
\hline
\end{tabular}

${ }^{1}$ Also including 3 hybrid ryegrass varieties.

${ }^{\circ} \mathrm{C}, 17.4{ }^{\circ} \mathrm{C}$ and $18.6{ }^{\circ} \mathrm{C}$ in Lodi, and $19.0^{\circ} \mathrm{C}$, $17.8^{\circ} \mathrm{C}$ and $17.3{ }^{\circ} \mathrm{C}$ in Perugia, respectively.

Total nitrogen fertilisation in each year of evaluation was $60 \mathrm{~kg} / \mathrm{ha}$ in both locations. All trials were mown 3-4 times according to an ordinary forage management, usually between the end of June and the end of October.

During the vegetative cycle of each trial, susceptibility to rust was scored every time the naturally-occurring symptoms were evident and able to differentiate the varieties. Accordingly, the number of records varied in the two locations and/or the three years of evaluation (Tab. 1). Being interested in the variety response over the whole growing season, when two or more disease scores were gathered they were averaged prior to data analysis. The scoring method of the disease was common to the European network and was based on a 9-point scale, estimating the percent leaf area affected by symptoms, and ranging from $1=$ no symptoms, to 9 $=$ over $75 \%$ of foliage covered with rust (Schubiger et al., 2007b). Wilkins (1978a) reported a strong correlation between a visual score for susceptibility and urediniospore production, emphasising the value of the visual score as a selection criterion.

The two rust species identified in both locations were stem rust (by Puccinia graminis Pers. subsp. graminicola Urban) and crown rust (by Puccinia coronata Corda f. sp. lolii Brown). In most cases, both Puccinia species were observed in a given trial, at the same time or in different periods. A separate score for each species was attributed to each plot with the same scale, after the unequivocal identification of the two pathogens and the respective symptoms. Following the network's criteria (Boller et al., 2003a), only records (of either pathogen) with a mean variety score $>2.0$ and a standard deviation of variety means $>0.6$ were retained for data analysis.

For each ryegrass species, the disease scores were subject to analysis of variance (ANOVA). Considering the response to the Puccinia species always present on a given Lolium species (that is, $P$. coronata on L. multiflorum and $P$. graminis on $L$. perenne, see Tab. 1 ), a combined ANOVA was carried out testing the main factors 'variety', 'location' and 'year' (all being fixed) and the respective interactions. Variety means were compared for each combination of year and location by individual ANOVAs and mean separation by least significant difference (LSD) at 5\% probability level. The mean score values of diploid and tetraploid germplasms were compared by ANOVA with linear contrast. Spearman rank correlation coefficients were computed for each ryegrass species between mean scores in different years in a given location, and mean scores in the two locations in each year of evaluation.

\section{Results}

In both locations, each Lolium species was mostly and consistently affected by one rust species, irrespective of the year. In particular, crown rust was always observed on Italian ryegrass, and stem rust on perennial ryegrass (Tab. 1 ). The alternative rust species on a given ryegrass, even when present, hardly caused severe symptoms. In most cases, the overall variety mean score for the secondary pathogen did not 
Table 2. Significance level of different sources of variation in the analysis of variance of rust susceptibility in ryegrass varieties evaluated for three years in two Italian locations.

\begin{tabular}{lcc}
\hline Source of variation & $\begin{array}{c}\text { Italian } \\
\text { ryegrass }^{1}\end{array}$ & $\begin{array}{c}\text { Perennial } \\
\text { ryegrass }^{2}\end{array}$ \\
\hline Variety (V) & $* * *$ & $* * *$ \\
Location (L) & $*$ & $* * *$ \\
Year (Y) & $* * *$ & $* * *$ \\
$\mathrm{~V} \times \mathrm{L}$ & $* * *$ & $* * *$ \\
$\mathrm{~V} \times \mathrm{Y}$ & $* * *$ & $* * *$ \\
$\mathrm{~L} \times \mathrm{Y}$ & $* * *$ & $* * *$ \\
$\mathrm{~V} \times \mathrm{L} \times \mathrm{Y}$ & $* * *$ & $* * *$
\end{tabular}

${ }^{1}$ Also including 3 hybrid ryegrass varieties. Rust species: Puccinia coronata.

${ }^{2}$ Rust species: Puccinia graminis.

*, ***: significant at $P<0.05$ and $P<0.001$, respectively.

exceed 2.0, and those records were not considered in the analysis. The only exception was an appreciable crown rust attack on perennial ryegrass recorded in Lodi both in 2004 and 2007 (Tab. 1).

Table 2 summarises the results of the com- bined ANOVA for crown rust on Italian ryegrass, and for stem rust on perennial ryegrass. In both species, all the main factors and their interactions showed significant variation (at $P<$ 0.001 in all but one case). Lodi and Perugia had different mean scores, higher in the former location for Italian ryegrass, and in the latter one for perennial ryegrass.

The scores of individual Italian ryegrass varieties in each location and year of evaluation are reported in Tab. 3. The overall mean score in the two locations varied considerably according to the year of evaluation, accounting for the 'location $x$ year' interaction. The interaction effects involving the varieties were explained by the greatly variable response of certain varieties in different locations and/or years. For instance, Pirol, Meryl and Barprisma showed higher scores in Lodi than in Perugia in 2001, but higher scores in Perugia than in Lodi in 2007.

Despite the occurrence of remarkable inter-

Table 3. Rust susceptibility scores (1: min; 9: $\max$ ) of 15 Italian ryegrass and three hybrid ryegrass varieties evaluated for three years in two Italian locations (rust species: Puccinia coronata). Tetraploid varieties $(4 \mathrm{x})$ are indicated in parentheses and are compared to diploids by linear contrast.

\begin{tabular}{|c|c|c|c|c|c|c|}
\hline \multirow[b]{2}{*}{ Variety } & \multicolumn{2}{|c|}{2001} & \multicolumn{2}{|c|}{2004} & \multicolumn{2}{|c|}{2007} \\
\hline & Lodi $^{2}$ & Perugia & Lodi & Perugia & Lodi & Perugia \\
\hline$\overline{\text { Gordo }}$ & $7.31 \mathrm{a}$ & $4.32 \mathrm{a}$ & $8.75 \mathrm{a}$ & $8.00 \mathrm{a}$ & $5.71 \mathrm{a}$ & $5.25 \mathrm{a}$ \\
\hline Gumpensteiner ${ }^{1}$ & $6.93 \mathrm{a}$ & $4.22 \mathrm{a}$ & $8.12 \mathrm{a}$ & $7.62 \mathrm{a}$ & $6.42 \mathrm{a}$ & $4.75 \mathrm{a}$ \\
\hline Lema & $7.31 \mathrm{a}$ & $3.82 \mathrm{a}$ & 6.75 & $7.62 \mathrm{a}$ & $5.08 \mathrm{a}$ & $4.75 \mathrm{a}$ \\
\hline Ligrande & $7.25 \mathrm{a}$ & $4.50 \mathrm{a}$ & 6.62 & $6.87 \mathrm{a}$ & $6.33 \mathrm{a}$ & $4.75 \mathrm{a}$ \\
\hline Lolita $(4 x)$ & 5.44 & $4.82 \mathrm{a}$ & 6.75 & $7.25 \mathrm{a}$ & $5.75 \mathrm{a}$ & $4.75 \mathrm{a}$ \\
\hline Danergo (4x) & 5.84 & $3.90 \mathrm{a}$ & 6.00 & 5.87 & $5.83 \mathrm{a}$ & $5.25 \mathrm{a}$ \\
\hline Pirol $^{1}$ & $6.50 \mathrm{a}$ & 3.65 & 3.87 & 6.37 & $2.83 \mathrm{~b}$ & 4.25 \\
\hline Ellire $(4 x)$ & 5.27 & 3.20 & 5.87 & 5.12 & $5.29 \mathrm{a}$ & 3.75 \\
\hline Meryl & 5.94 & $2.67 \mathrm{~b}$ & 4.25 & 5.25 & $2.75 \mathrm{~b}$ & 4.00 \\
\hline Fastyl & 5.00 & 3.32 & 4.00 & 4.87 & $2.17 \mathrm{~b}$ & 3.50 \\
\hline Barprisma & 5.25 & $2.42 \mathrm{~b}$ & 3.25 & $3.87 \mathrm{~b}$ & $1.67 \mathrm{~b}$ & 3.75 \\
\hline Aberexcel $^{1}(4 x)$ & $3.37 \mathrm{~b}$ & 3.17 & 3.62 & $3.87 \mathrm{~b}$ & 4.00 & 3.75 \\
\hline Tonyl $(4 \mathrm{x})$ & $4.05 \mathrm{~b}$ & $2.57 \mathrm{~b}$ & 3.12 & $3.87 \mathrm{~b}$ & 3.08 & $2.75 \mathrm{~b}$ \\
\hline Bolero (4x) & $3.56 \mathrm{~b}$ & $2.70 \mathrm{~b}$ & 3.75 & $3.50 \mathrm{~b}$ & $2.54 \mathrm{~b}$ & 3.25 \\
\hline Domino $(4 \mathrm{x})$ & $3.31 \mathrm{~b}$ & $2.60 \mathrm{~b}$ & $1.87 \mathrm{~b}$ & $4.25 \mathrm{~b}$ & 3.58 & 3.50 \\
\hline Zorro (4x) & $4.00 \mathrm{~b}$ & $1.92 \mathrm{~b}$ & $2.12 \mathrm{~b}$ & $3.62 \mathrm{~b}$ & 3.33 & 3.50 \\
\hline Caballo (4x) & $3.19 \mathrm{~b}$ & $2.90 \mathrm{~b}$ & $1.50 \mathrm{~b}$ & $3.87 \mathrm{~b}$ & 3.08 & $3.00 \mathrm{~b}$ \\
\hline Tarandus $(4 \mathrm{x})$ & $3.69 \mathrm{~b}$ & $1.90 \mathrm{~b}$ & $1.87 \mathrm{~b}$ & $3.37 \mathrm{~b}$ & $1.25 \mathrm{~b}$ & $2.50 \mathrm{~b}$ \\
\hline Mean & 5.18 & 3.26 & 4.56 & 5.28 & 3.93 & 3.94 \\
\hline LSD (5\%) & 0.98 & 1.07 & 1.42 & 1.44 & 1.77 & 0.77 \\
\hline Diploids $^{3}$ & $6.44^{* * * *}$ & $3.62^{* * *}$ & $5.70^{* * * *}$ & $6.31^{* * * *}$ & $4.12 \mathrm{~ns}$ & $4.37^{* * * *}$ \\
\hline Tetraploids & 4.17 & 2.97 & 3.65 & 4.46 & 3.77 & 3.60 \\
\hline
\end{tabular}

${ }^{1}$ Lolium $\times$ boucheanum (hybrid ryegrass).

${ }^{2}$ In each column, values followed by letters 'a' and 'b' do not differ from the top-ranking and bottom-ranking value, respectively, according to LSD. In italics, variety names whose values were consistently in either extreme group in all environments.

${ }^{3} \mathrm{~ns}, *, * *, * *$ : mean values of diploid and tetraploid varieties not different and different at $P<0.05, P<0.01$ and $P<0.001$, respectively, according to linear contrast. 
Table 4. Rust susceptibility scores (1: $\min$; 9: $\max$ ) of 33 perennial ryegrass varieties evaluated for three years in two Italian locations (rust species: Puccinia graminis). Tetraploid varieties $(4 \mathrm{x})$ are indicated in parentheses and are compared to diploids by linear contrast.

\begin{tabular}{|c|c|c|c|c|c|c|}
\hline \multirow[b]{2}{*}{ Variety } & \multicolumn{2}{|c|}{2001} & \multicolumn{2}{|c|}{2004} & \multicolumn{2}{|c|}{2007} \\
\hline & $\operatorname{Lodi}^{1}$ & Perugia & Lodi & Perugia & Lodi & Perugia \\
\hline Lipresso & $6.37 \mathrm{a}$ & 5.00 & $7.50 \mathrm{a}$ & $6.87 \mathrm{a}$ & $5.55 \mathrm{a}$ & $3.25 \mathrm{a}$ \\
\hline Aurora & $6.62 \mathrm{a}$ & 4.85 & 4.00 & $6.75 \mathrm{a}$ & 4.00 & $3.50 \mathrm{a}$ \\
\hline Corbet & $6.69 \mathrm{a}$ & $5.77 \mathrm{a}$ & 3.87 & 5.75 & 3.37 & $3.25 \mathrm{a}$ \\
\hline Fennema & $5.81 \mathrm{a}$ & $5.50 \mathrm{a}$ & 3.62 & $5.87 \mathrm{a}$ & 2.50 & $3.00 \mathrm{a}$ \\
\hline Arabella & $6.37 \mathrm{a}$ & $5.42 \mathrm{a}$ & 3.37 & 5.50 & $4.37 \mathrm{a}$ & $3.75 \mathrm{a}$ \\
\hline Vincent & 5.00 & $5.32 \mathrm{a}$ & 4.37 & 5.37 & 2.87 & $3.50 \mathrm{a}$ \\
\hline Heraut & 4.62 & $5.42 \mathrm{a}$ & 5.00 & 5.00 & $2.12 \mathrm{~b}$ & $3.50 \mathrm{a}$ \\
\hline Gladio & 4.94 & 4.35 & 5.62 & 4.87 & 3.25 & 2.75 \\
\hline Weigra & $6.19 \mathrm{a}$ & $5.42 \mathrm{a}$ & $2.12 \mathrm{~b}$ & 5.25 & $4.75 \mathrm{a}$ & $3.50 \mathrm{a}$ \\
\hline Kells & $5.94 \mathrm{a}$ & $5.27 \mathrm{a}$ & 2.87 & 4.87 & 3.06 & $3.50 \mathrm{a}$ \\
\hline Guru & 4.75 & 4.07 & 3.50 & $6.25 \mathrm{a}$ & 2.75 & $3.25 \mathrm{a}$ \\
\hline Litempo (4x) & 3.61 & 3.85 & $6.25 \mathrm{a}$ & 4.62 & 3.00 & 2.75 \\
\hline Roy $(4 x)$ & 3.44 & 3.67 & 6.00 & 4.87 & $1.62 \mathrm{~b}$ & $2.00 \mathrm{a}$ \\
\hline Helmer $(4 x)$ & 3.19 & 4.30 & 6.00 & 4.37 & $2.00 \mathrm{~b}$ & $3.25 \mathrm{a}$ \\
\hline Sirocco $(4 x)$ & 4.75 & 4.07 & 4.25 & 4.75 & 2.75 & 2.75 \\
\hline Condesa $(4 \mathrm{x})$ & 4.05 & 3.57 & 5.00 & 5.12 & $1.62 \mathrm{~b}$ & 2.75 \\
\hline Option & 4.00 & $5.82 \mathrm{a}$ & 2.62 & 5.00 & 3.50 & $4.00 \mathrm{a}$ \\
\hline Sponsor & 4.94 & $5.40 \mathrm{a}$ & $1.87 \mathrm{~b}$ & 4.75 & 2.94 & $3.50 \mathrm{a}$ \\
\hline Lacerta $(4 \mathrm{x})$ & 3.81 & $3.47 \mathrm{~b}$ & 5.12 & 4.50 & 3.25 & 2.50 \\
\hline Barnhem & 4.75 & 4.27 & 1.87 & 5.25 & 4.00 & $3.25 \mathrm{a}$ \\
\hline Terry (4x) & $3.06 \mathrm{~b}$ & $3.32 \mathrm{~b}$ & 4.75 & 5.00 & $2.37 \mathrm{~b}$ & $2.25 \mathrm{~b}$ \\
\hline Aristo & 4.00 & 4.57 & 2.75 & 4.50 & 2.50 & 2.50 \\
\hline Aberdart & 3.75 & 3.67 & 3.50 & 4.62 & $1.75 \mathrm{~b}$ & 2.50 \\
\hline Kentaur (4x) & 3.02 & 3.75 & 3.87 & 4.75 & $2.06 \mathrm{~b}$ & 2.50 \\
\hline Foxtrot & 4.37 & 4.75 & $1.25 \mathrm{~b}$ & 4.62 & $2.37 \mathrm{~b}$ & $3.25 \mathrm{a}$ \\
\hline Tivoli (4x) & 3.50 & 3.52 & 3.37 & 4.50 & $1.75 \mathrm{~b}$ & $1.75 \mathrm{~b}$ \\
\hline Orval & 3.25 & 4.15 & 3.37 & $3.87 \mathrm{~b}$ & $1.62 \mathrm{~b}$ & $2.25 \mathrm{~b}$ \\
\hline Carrera & 4.25 & $3.47 \mathrm{~b}$ & $1.25 \mathrm{~b}$ & 4.25 & 2.50 & 2.50 \\
\hline Aubisque $(4 x)$ & $2.56 \mathrm{~b}$ & 4.17 & $1.62 \mathrm{~b}$ & $4.00 \mathrm{~b}$ & $1.62 \mathrm{~b}$ & 2.50 \\
\hline Pastoral (4x) & $2.37 \mathrm{~b}$ & $3.07 \mathrm{~b}$ & $2.00 \mathrm{~b}$ & $3.50 \mathrm{~b}$ & $1.62 \mathrm{~b}$ & $1.75 \mathrm{~b}$ \\
\hline Elgon $(4 \mathrm{x})$ & $3.00 \mathrm{~b}$ & $3.07 \mathrm{~b}$ & $1.12 \mathrm{~b}$ & $3.75 \mathrm{~b}$ & $1.75 \mathrm{~b}$ & $1.75 \mathrm{~b}$ \\
\hline Bocage $(4 x)$ & $2.75 \mathrm{~b}$ & 3.82 & $1.37 \mathrm{~b}$ & $3.00 \mathrm{~b}$ & $1.62 \mathrm{~b}$ & 2.50 \\
\hline Gwendal (4x) & $2.11 \mathrm{~b}$ & $2.75 \mathrm{~b}$ & $1.12 \mathrm{~b}$ & $3.50 \mathrm{~b}$ & $1.12 \mathrm{~b}$ & $1.25 \mathrm{~b}$ \\
\hline Mean & 4.30 & 4.33 & 3.52 & 4.83 & 2.66 & 2.81 \\
\hline LSD (5\%) & 1.01 & 0.74 & 1.42 & 1.01 & 1.33 & 1.15 \\
\hline Diploids $^{2}$ & $5.08^{* * *}$ & $4.87^{* * *}$ & $3.38 \mathrm{~ns}$ & $5.22^{* * * *}$ & $3.14^{* * *}$ & $3.18^{* * * *}$ \\
\hline Tetraploids & 3.23 & 3.60 & 3.70 & 4.30 & 2.01 & 2.30 \\
\hline
\end{tabular}

${ }^{1}$ In each column, values followed by letters ' $a$ ' and ' $b$ ' do not differ from the top-ranking and bottom-ranking value, respectively, according to LSD. In italics, variety names whose values were consistently in either extreme group in all environments.

${ }^{2} \mathrm{~ns}, *, * *, * *$ : mean values of diploid and tetraploid varieties not different and different at $P<0.05, P<0.01$ and $P<0.001$, respectively, according to linear contrast.

actions, some varieties showed a consistent behaviour across evaluation environments (combinations of locations and years). Gordo was top-ranking for susceptibility, and Tarandus was bottom-ranking, in four environments out of six (Tab. 3). Statistically, Gumpensteiner was also always included among the highest-susceptible varieties (Tab. 3), and Caballo was another variety of possible interest for its disease tolerance, being in the group of the least-susceptible varieties in five environments out of six (Tab. 3).

To a large extent, the inconsistency of variety responses across evaluation environments in perennial ryegrass varieties appeared to be greater than in Italian ryegrass varieties (Tab. 4). As a matter of fact, several perennial ryegrass varieties showed marked inconsistency, such as Arabella, Kells, Litempo, Helmer, Sponsor, Barnhem or Foxtrot, just to mention some of them (Tab. 4). In particular, the individual 
disease scores in Lodi and Perugia in 2004 seemed to be mostly inconsistent in the presence of a difference between overall location mean scores which was the largest of the three years (Tab. 4).

Nonetheless, also in perennial ryegrass some varieties were noticeable for their consistent behaviour. In particular, Pastoral, Elgon and Gwendal always appeared among the least-susceptible varieties, with Gwendal being the bottom-ranking variety in five out of six experimental conditions (Tab. 4). Because of the strong variety $\times$ year and/or variety $\times$ location interaction, no variety was consistently included among the most-susceptible ones in statistical terms. However, Lipresso was among the highest-scoring varieties in five cases out of six, and in three cases it was the top-ranking variety, highlighting its susceptibility to stem rust (Tab. 4).

A clear and fairly consistent trend was present in both ryegrass species in most evaluation environments, with diploid varieties displaying higher susceptibility than tetraploid varieties (Tabb. 3 and 4). The same trend was also confirmed when only the 15 true L. multiflorum varieties were considered (data not reported).

The repeatability of disease assessment in different years and different locations was assessed by computing Spearman rank correlations. As for Italian ryegrass, the correlation in Lodi was fairly high between 2001 and 2004 results, but only low to moderate (although significant at $P<0.05$ ) between 2001 and 2007, and between 2004 and 2007. In Perugia, all three between-year correlations were similar, with $r>$ 0.80 , and highly significant (Tab. 5).

Between-year correlations in perennial ryegrass were generally lower than those in Italian ryegrass, with the exception of that between 2001 and 2007, which exceeded 0.80 in both locations. The two other correlations did not reach the significance level at $P<0.05$ in Lodi, but were significant $(r>0.70)$ in Perugia (Tab. 5).
Table 5. Spearman rank correlation coefficients among mean rust susceptibility scores of ryegrass varieties in three years of evaluation in two Italian locations.

\begin{tabular}{lcccc}
\hline & \multicolumn{2}{c}{ Italian ryegrass $^{1}$} & \multicolumn{2}{c}{ Perennial ryegrass } \\
\cline { 2 - 5 } & 2004 & 2007 & 2004 & 2007 \\
\hline Lodi & & & & \\
2001 & $0.87^{* * *}$ & $0.49^{*}$ & $0.24 \mathrm{~ns}$ & $0.81^{* * *}$ \\
2004 & - & $0.67^{* *}$ & - & $0.23 \mathrm{~ns}$ \\
Perugia & & & & \\
2001 & $0.86^{* * *}$ & $0.81^{* * *}$ & $0.62^{* * *}$ & $0.86^{* * *}$ \\
2004 & - & $0.88^{* * *}$ & - & $0.69^{* * *}$ \\
\hline
\end{tabular}

${ }^{1}$ Rust species: Puccinia coronata; $\mathrm{N}=18$ (including 3 hybrid ryegrass varieties).

2 Rust species: Puccinia graminis; $\mathrm{N}=33$.

ns, *,**,***: not significant and significant at $P<0.05, P<0.01$ and $P<0.001$, respectively.

The variety rank correlations between the two locations were significant $(P<0.01)$ in both ryegrass species (Tab. 6). However, except in 2004 for Italian ryegrass, the magnitude of the correlation coefficients was never particularly large, especially for perennial ryegrass (Tab. 6).

When $P$. coronata was also recorded in an appreciable manner on perennial ryegrass varieties, the mean variety scores reported in Table 7 were obtained. The crown rust attack in 2007 was much milder and less able to discriminate among varieties than in 2004. Although referring to only those two evaluation environments, some varieties with consistent response to crown rust were observed. In particular, Sirocco, Helmer, Litempo and Gladio were susceptible to this disease, whereas Vincent, Weigra, Aristo and Gwendal did not show any symptom of crown rust, and other varieties were only mildly affected in 2004 (Tab. 7). Interestingly, none of the varieties most affected by crown rust appeared among the most-susceptible to stem rust (see Tab. 4). Weigra, which was symptomless to crown rust, was remarkably attacked by stem rust. Pending a confirmation under $a d$ hoc crown rust infection trials, Pastoral, Elgon,

Table 6. Spearman rank correlation coefficients between mean rust susceptibility scores of ryegrass varieties in two Italian locations in each year of evaluation.

\begin{tabular}{lcccccc}
\hline & \multicolumn{3}{c}{ Italian ryegrass $^{1}$} & \multicolumn{3}{c}{ Perennial ryegrass $^{2}$} \\
\cline { 2 - 7 } & 2001 & 2004 & 2007 & 2001 & 2004 & 2007 \\
\hline Lodi vs Perugia & $0.67^{* *}$ & $0.88^{* * *}$ & $0.72^{* * *}$ & $0.74^{* * *}$ & $0.45^{* *}$ & $0.73^{* * *}$ \\
\hline
\end{tabular}

${ }^{1}$ Rust species: Puccinia coronata; $\mathrm{N}=18$ (including 3 hybrid ryegrass varieties).

${ }^{2}$ Rust species: Puccinia graminis; $\mathrm{N}=33$.

**, ***: significant at $P<0.01$ and $P<0.001$, respectively. 
Table 7. Susceptibility scores (1: $\min ; 9: \max )$ to Puccinia coronata of 33 perennial ryegrass varieties in Lodi. Tetraploid varieties $(4 \mathrm{x})$ are indicated in parentheses; all other varieties are diploid.

\begin{tabular}{lll}
\hline & \multicolumn{2}{c}{ Lodi } \\
\cline { 2 - 3 } Variety & 2004 & 2007 \\
\hline Lipresso & 6.00 & $2.00 \mathrm{~b}$ \\
Aurora & 6.00 & $2.00 \mathrm{~b}$ \\
Corbet & 3.00 & $1.00 \mathrm{~b}$ \\
Fennema & 6.25 & $1.00 \mathrm{~b}$ \\
Arabella & 5.00 & $1.00 \mathrm{~b}$ \\
Vincent & $1.00 \mathrm{~b}$ & $1.00 \mathrm{~b}$ \\
Heraut & 5.75 & $1.00 \mathrm{~b}$ \\
Gladio & $7.50 \mathrm{a}$ & $4.50 \mathrm{a}$ \\
Weigra & $1.00 \mathrm{~b}$ & $1.00 \mathrm{~b}$ \\
Kells & 4.25 & $1.00 \mathrm{~b}$ \\
Guru & 4.25 & $1.00 \mathrm{~b}$ \\
Litempo $(4 \mathrm{x})$ & $7.25 \mathrm{a}$ & $5.75 \mathrm{a}$ \\
Roy $(4 \mathrm{x})$ & 6.50 & $3.00 \mathrm{~b}$ \\
Helmer $(4 \mathrm{x})$ & $8.00 \mathrm{a}$ & $6.00 \mathrm{a}$ \\
Sirocco $(4 \mathrm{x})$ & $8.75 \mathrm{a}$ & $6.50 \mathrm{a}$ \\
Condesa $(4 \mathrm{x})$ & $8.25 \mathrm{a}$ & 3.75 \\
Option & 4.75 & $1.00 \mathrm{~b}$ \\
Sponsor & $2.50 \mathrm{~b}$ & $1.00 \mathrm{~b}$ \\
Lacerta $(4 \mathrm{x})$ & $7.50 \mathrm{a}$ & $1.00 \mathrm{~b}$ \\
Barnhem & 3.50 & $1.12 \mathrm{~b}$ \\
Terry (4x) & 5.25 & $1.00 \mathrm{~b}$ \\
Aristo & $1.00 \mathrm{~b}$ & $1.00 \mathrm{~b}$ \\
Aberdart & $7.50 \mathrm{a}$ & $1.00 \mathrm{~b}$ \\
Kentaur $(4 \mathrm{x})$ & 4.50 & 3.50 \\
Foxtrot & 4.50 & $1.25 \mathrm{~b}$ \\
Tivoli $(4 \mathrm{x})$ & 6.75 & 3.25 \\
Orval & 6.00 & $5.00 \mathrm{a}$ \\
Carrera & $1.25 \mathrm{~b}$ & $1.00 \mathrm{~b}$ \\
Aubisque $(4 \mathrm{x})$ & 4.25 & $1.75 \mathrm{~b}$ \\
Pastoral $(4 \mathrm{x})$ & $1.75 \mathrm{~b}$ & $1.75 \mathrm{~b}$ \\
Elgon $(4 \mathrm{x})$ & $2.00 \mathrm{~b}$ & $1.75 \mathrm{~b}$ \\
Bocage $(4 \mathrm{x})$ & $2.25 \mathrm{~b}$ & $1.00 \mathrm{~b}$ \\
Gwendal $(4 \mathrm{x})$ & $1.00 \mathrm{~b}$ & $1.00 \mathrm{~b}$ \\
Mean & 4.70 & 2.20 \\
LSD $(5 \%)$ & 1.92 & \\
\hline In & & \\
\hline
\end{tabular}

In each column, values followed by letters ' $a$ ' and ' $b$ ' do not differ from the top-ranking and bottom-ranking value, respectively, according to LSD. In italics, varieties whose values were consistently in either extreme group in both years.

Bocage and Gwendal seemed to possess a composite resistance towards both stem rust and crown rust (Tabb. 4 and 8). The rank correlation coefficient between the mean score for the two pathogens was positive and significant in 2004 $(r=0.70, P<0.001)$ but was not different from zero in $2007(r=-0.21, P>0.22)$, where the results for crown rust were at the limit for consideration (mean score $=2.12$ ) and probably less reliable than those in 2004.

In 2004 no significant difference was found in mean susceptibility to crown rust in diploid and tetraploid perennial ryegrass varieties. In 2007 a significantly higher mean score was observed in tetraploid than in diploid varieties, although both values were rather low on the infection scale (2.93 vs $1.52, P<0.05$, respectively).

\section{Discussion}

Boller et al. (2003a) and Schubiger et al. (2007b) summarised the European network's results for the first (2001) and second (2004) year of evaluation, respectively. The present findings agree with the observations at the continental level (across 30 sites) reporting crown rust as the sole rust species seriously affecting Italian ryegrass, and stem rust being present on perennial ryegrass almost exclusively in eastern and southern Europe. Stem rust is primarily a warm-weather disease (Leonard and Szabo, 2005). The predominance of crown rust also on perennial ryegrass in central and northern Europe and in Australia, where this forage species is widespread, makes this pathogen to be perceived as the most important fungal pathogen on ryegrasses (Potter et al., 1990; Roderick and Thomas, 1997; Aldaoud et al., 2004) and arises vast interest on the crop resistance to this disease (e.g. Wilkins, 1978a; 1978b; Roderick et al., 2000; Muylle et al., 2005; Schejbel et al., 2007; Studer et al., 2007; Sim et al., 2007).

Considering the distribution of the two pathogen species in Europe, specific breeding programmes for the enhancement of stem rust resistance in areas where this species occurs would be advisable. Nowadays, most perennial ryegrass selection is carried out in regions especially prone to crown rust, and the risk may exist of varieties selected under this pathogen's pressure to be misadapted where stem rust predominates. The present results seem to reassure that some perennial ryegrass varieties are provided with a possible resistance/tolerance to both rust species. A thorough confirmation of their response to crown rust (by $P$. coronata f. sp. lolii) in Italian environments would be needed, given the occasional occurrence of this species during the evaluation. However, at least Gwendal, Bocage and Pastoral have shown a generalised tolerance to crown rust across $\mathrm{Eu}-$ rope (Schubiger et al., 2007b). Apart from a few varieties, in the current investigation there seemed to be a weak correspondence of variety 
response to the two rust species, in analogy with the European network's results (Boller et al., 2003a).

Resistance to crown rust in perennial ryegrass may be under major gene [reported by Potter et al. (1990)] or polygene control (Hayward, 1977). More recently, the use of molecular marker systems has revealed different quantitative trait loci (QTLs) for resistance (Muylle et al., 2005; Schejbel et al., 2007). A few genes with major effects (Hides and Wilkins, 1978) and QTLs of resistance (Studer et al., 2007) have also been reported for crown rust in Italian ryegrass, where a maternal effect on resistance has additionally been observed (Adams et al., 2000). Much more scanty seems to be the knowledge on the genetic control of stem rust resistance in perennial ryegrass. Rose-Fricker et al. (1986) suggested that this resistance was predominantly quantitatively inherited with minor and possibly some major genes. Should the occurrence of varieties with resistance to both rust species be further supported, a possible efficacy of certain major gene(s) and/or QTL(s) towards both pathogens could be postulated.

The potential race-specificity of the identified resistance determinants is largely unknown. Studer et al. (2007) found differences in position and magnitude of QTLs among individual evaluation locations, suggesting a differential quantitative response to local pathogen races. The ability of crown rust isolates to overcome major genes conferring resistance to a range of other isolates has been reported in Europe (Potter et al., 1990) and Australia (Aldaoud et al., 2004). In addition to race specialisation, environmental effects might also influence rust resistance (Roderick et al., 2000). Given the array of possible combinations between genetic variation of the pathogen and different environmental conditions, it was no surprise to find the current strong interaction effects on the varietal response to the disease, and the sometimes only moderate or low repeatability of response between years and/or locations. However, whether this was due to a predominant effect of races, environmental differences (for instance, the difference in moisture or temperatures between Lodi and Perugia), or both, cannot be ascertained.

Although in the presence of $\mathrm{G} \times \mathrm{E}$ interactions, it was worth noting that some varieties of both ryegrass species had a fairly consistent response of "susceptibility" or "tolerance" across environments. Interestingly, the varieties with the lowest mean scores, such as Tarandus in Italian ryegrass, and Gwendal, Pastoral, Bocage and Elgon in perennial ryegrass, were also among the least-affected by the same pathogens at the continental level (Boller et al., 2003a; Schubiger et al., 2007b), thus suggesting a stability even across more diversified sites than Lodi and Perugia. The relative stability of ranking observed for these varieties might imply the presence of a polygenic resistance to rust.

The trend of a greater rust tolerance in tetraploid than diploid varieties here observed is in line with a general opinion of a better resistance to leaf diseases in tetraploid cultivars of ryegrasses compared to diploid germplasm (Boller et al., 2003b). However, the current results suggest that more evidence is needed regarding the resistance to crown rust in perennial ryegrass. Greater dosage of resistance genes determined by the chromosome doubling, or a deliberate exclusion of markedly disease-susceptible diploid plants from the polyploidisation process, are both reasons for the possible advantage of tetraploids over the diploids in disease tolerance. The theoretical approach proposed by Oswald and Nuismer (2007) suggests that, in the presence of a gene-for-gene or an inverse matching alleles model of genetic mechanism of pathogen resistance, tetraploids are expected to be more resistant than their diploid progenitors.

This study brought forward the great variation in rust susceptibility in Italy of a large set of varieties, which had never been evaluated before in this country. The varietal response appeared to be possibly influenced by external factors (environmental conditions and/or physiological races of pathogens), and the repeatability of results subsequently affected. The varieties with consistently low susceptibility might have a potential for direct introduction into cultivation (provided other agronomic features are at least satisfactory and appropriate for the local conditions) and/or as possible donors of useful genes for breeding purposes.

\section{References}

Adams E., Roldan-Ruiz I., Depicker A., van Bockstaele E., De Loose M. 2000. A maternal factor conferring resistance to crown rust in Lolium multiflorum cv. 'Axis'. Plant Breeding, 119:182-184. 
Aldaoud R., Anderson M.W., Reed K.F.M., Smith K.F. 2004. Evidence of pathotypes among Australian isolates of crown rust infecting perennial ryegrass. Plant Breeding, 123:395-397.

Beard J.B. 1973. Turfgrass science and culture. Englewood, Cliff, NJ. Prentice Hall Inc.

Boller B., Schubiger F.X., Streckeisen P., Baert J., Bayle B., Bourdon P., Dijkstra J., Eickmeyer F., Feuerstein U., Jakesova H., Jönsson H.-A., Krautzer B., Lellbach H., Louwerse L., McAneney D., Posselt U.K., Romani M., Rössl G., Russi L., Schulze S., Tardin M.-C., Thiemt E., VanHee F., Wilkins P., Willner E., Wolters L. 2003a. The EUCARPIA multisite rust evaluation - results 2001. Vorträge für Pflanzenzuchtung, 59: 198-207.

Boller B., Schubiger F.X., Tanner P. 2003b. Can organic agriculture abandon tetraploid varieties of red clover and ryegrass? In: Ruckenbauer P., Raab F., Kern R., Buchgraber K. (eds.): Bericht über die Arbeitstagung 2002 der Vereinigung der Pflanzenzuchter und Saatgutkaufleute Österreichs. Gumpenstein Irdning: Bundesanstalt für Alpenlandische Lanwirtschaft. 71-74.

Clarke R.G., Villalta O.N., Hepworth G. 1997. Evaluation of resistance to five isolates of Puccinia coronata f. sp. lolii in 19 perennial ryegrass cultivars. Australian Journal of Agricultural Research, 48:191-198.

Hayward M.D. 1977. Genetic control of resistance to crown rust (Puccinia coronata Corda) in Lolium perenne and its implications in breeding. Theoretical and Applied Genetics, 51:49-53.

Hides D.H., Wilkins P.W. 1978. Selection for resistance to ryegrass mosaic virus and crown rust (Puccinia coronata Corda) in Italian ryegrass populations. Journal of the British Grassland Society, 33:253-260.

Jung G.A., Van Wijk A.J.P., Hunt W.F., Watson C.E. 1996. Ryegrasses. In: Moser L.E., Buxton D.R., Casler M.D. (eds.): Cool-Season Forage Grasses, 605-642. Madison, WI. ASA, CSSA, SSSA.

Kimbeng C.A. 1999. Genetic basis of crown rust resistance in perennial ryegrass, breeding strategies, and genetic variation among pathogen population: a review. Australian Journal of Experimental Agriculture, 39:361-378.

Leonard K.J., Szabo L.J. 2005. Stem rust of small grains and grasses caused by Puccinia graminis. Molecular Plant Pathology, 6:99-111.

Muylle H., Baert J., van Bockstaele E., Pertijs J., RoldanRuiz I. 2005. Four QTLs determine crown rust (Puccinia coronata $\mathrm{f}$. sp. lolii) resistance in a perennial ryegrass (Lolium perenne) population. Heredity, 95: 348-357.

Oswald B.P., Nuismer S.L. 2007. Neopolyploidy and pathogen resistance. Proceedings of the Royal Society, Series B, Biological Sciences, 274:2393-2397.

Potter L.R. 1987. Effect of crown rust on regrowth, com- petitive ability and nutritional quality of perennial and Italian ryegrasses. Plant Pathology, 36:455-461.

Potter L.R., Cagas B., Paul V.H., Birckenstaedt E. 1990. Pathogenicity of some European collections of crown rust (Puccinia coronata Corda) on cultivars of perennial ryegrass. Journal of Phytopathology, 130:119-126.

Roderick H.W., Thomas B.J. 1997. Infection of ryegrass by three rust fungi (Puccinia coronata, $P$. graminis and $P$. loliina) and some effects of temperature on the establishment of the disease and sporulation. Plant Pathology, 46:751-761.

Roderick H.W., Thorogood D., Adomako B. 2000. Temperature-dependent resistance to crown rust infection in perennial ryegrass, Lolium perenne. Plant Breeding, 119:93-95.

Rose-Fricker C.A., Meyer W.A., Kronstad W.E. 1986. Inheritance of resistance to stem rust (Puccinia graminis subsp. graminicola) in six perennial ryegrass (Lolium perenne) crosses. Plant Disease, 70:678-681.

Schejbel B., Jensen L.B., Xing Y., Lubberstedt T. 2007. QTL analysis of crown rust resistance in perennial ryegrass under conditions of natural and artificial infection. Plant Breeding, 126:347-352.

Schubiger F.X., Hurlimann H., Schlappi K., Streckeisen P., Boller B. 2007a. Virulence of crown rust isolates on genotypes of Italian and perennial ryegrass. In: Rosellini D., Veronesi F. (eds.): Breeding and seed production for conventional and organic agriculture, 301-306. Università di Perugia, Italy.

Schubiger F.X., Streckeisen P., Boller B. 2007b. The EUCARPIA multisite rust evaluation - results 2004. In: Rosellini D., Veronesi F. (eds.): Breeding and seed production for conventional and organic agriculture, 154-158. Università di Perugia, Italy.

Sim S., Diesburg K., Casler M., Jung G. 2007. Mapping and comparative analysis of QTL for crown rust resistance in an Italian $x$ perennial ryegrass population. Phytopathology, 97:767-776.

Studer B., Boller B., Bauer E., Posselt U.K., Widmer F., Kolliker R. 2007. Consistent detection of QTL for crown rust resistance in Italian ryegrass (Lolium multiflorum Lam.) across environments and phenotyping methods. Theoretical and Applied Genetics, 115:9-17.

Tomasoni C., Borrelli L., Pecetti L. 2003. Influence of fodder crop rotations on the potential weed flora in the irrigated lowlands of Lombardy, Italy. European Journal of Agronomy, 19:439-451.

Wilkins P.W. 1978a. Specialisation of crown rust (Puccinia coronata Corda) on clones of Italian ryegrass (Lolium multiflorum Lam.). Euphytica, 27:837-841.

Wilkins P.W. 1978b. Specialisation of crown rust on highly and moderately resistant plants of perennial ryegrass. Annals of Applied Biology, 88:179-184. 